Article

\title{
A Foe of Democracy, Gender and Sexual Equality in Macedonia: The Worrisome Role of the Party VMRO-DPMNE
}

\author{
Ana Miškovska Kajevska \\ Political Science Department, University of Amsterdam, 1012 DL, Amsterdam, The Netherlands; \\ E-Mail: A.MishkovskaKajevska@uva.nl
}

Submitted: 9 February 2018 | Accepted: 14 June 2018 | Published: 14 September 2018

\begin{abstract}
Between 2006 and 2017, the political power in the Republic of Macedonia was predominantly held by the Christiandemocratic party VMRO-DPMNE. Its increasing opposition to gender and sexual equality manifested, inter alia, in the imposition of an antidiscrimination law, which did not explicitly recognise sexual orientation as a ground of discrimination, the replacement of the rather liberal abortion law with a restrictive one, and the two attempts to constitutionally define marriage as a heterosexual union. Building upon earlier inquiries into the development of the LGBT movement in Macedonia and the introduction of the new abortion law, I examine here the discourse which the ruling coalitions used to justify the removal of the term 'sexual orientation' from the antidiscrimination law, and the need for a constitutional definition of marriage. I explore further how the authorities pushed their conservative agenda by undermining democracy through infringement of the official legislative procedures and suppression of dissent. In closing, I underline the retrograde impact of de-democratisation on the already and the yet to be attained progressive legislation and practices in the realm of gender and sexual equality.
\end{abstract}

\section{Keywords}

antidiscrimination law; constitutional definition of marriage; de-democratisation; gender equality; Macedonia; NGOs; party VMRO-DPMNE; sexual equality; state capture

\section{Issue}

This article is part of the issue "The Feminist Project under Threat in Europe", edited by Mieke Verloo (Radboud University, The Netherlands) and David Paternotte (Université Libre de Bruxelles, Belgium).

(C) 2018 by the author; licensee Cogitatio (Lisbon, Portugal). This article is licensed under a Creative Commons Attribution 4.0 International License (CC BY).

\section{Introduction}

Between 2006 and 2017, the political power in the Republic of Macedonia was predominantly held by the Christian-democratic party Internal Macedonian Revolutionary Organisation-Democratic Party for Macedonian National Unity (VMRO-DPMNE). Its opposition to gender and sexual equality manifested, inter alia, in the imposition in April 2010 of an antidiscrimination lawMacedonia's first one-which did not explicitly recognise sexual orientation as a ground of discrimination, the replacement of the rather liberal abortion law with a restrictive one in June 2013, and the two attempts (August/September 2013, and June 2014/January 2015) to constitutionally define marriage as a heterosexual union.
During VMRO-DPMNE's rule, there was not only a proliferation of discriminatory discourses (including those employed by state officials) and anti-LGBT violence, but also a virtual impunity of the perpetrators, despite the existence of Criminal Code which proscribed physical violence against people and discrimination based on personal characteristics (e.g., Služben vesnik na Republika Makedonija, 37/1996). This dismantling of the already vulnerable nascent rule of law was also visible in the way in which the new abortion law came about. In fact, the interference with the freedom of choice regarding childbirth proved to be an excellent case for observing the state-led interference with other human rights and freedoms, and learning more about the mechanisms of dedemocratisation (Miškovska Kajevska, 2016, 2018). 
As in my analysis of the installation of a new abortion law (Miškovska Kajevska, 2018), I use the term 'de-democratisation' to refer to the various legislative breaches and other forms of disregard of official procedures, which were undertaken by the authorities themselves. Building upon Walby's assertion (2011, p. 11) that 'the shrinking of democratic spaces makes for a more difficult environment for the operation of feminism, which attempts to reduce inequalities and to deepen democratic governance', I set here to explore the interaction between de-democratisation and opposition to gender and sexual equality further. I examine the discourse which the Macedonian authorities used in their successful efforts to remove the term 'sexual orientation' from the draft antidiscrimination law and their unsuccessful endeavours to constitutionally define marriage. In addition, I look into the ways in which the ruling coalitions pushed their conservative agenda on those occasions by repeatedly infringing the official legislative procedures and readily discarding the criticism, which was put forward by the parliamentary and NGO opposition, as well as international and supranational institutions. My findings are based on the data obtained from official documents of the government and parliament of Macedonia, media statements, and publications by (LGBT) human rights NGOs. ${ }^{1}$

I begin by introducing the Macedonian legal context in relation to the antidiscrimination law and the legal definition of marriage. Subsequently, following the chronological order of the analysed instances of law-making, I scrutinise the related legislative procedure and the accompanying discourse. The thick descriptions, which I employ, lend themselves valuable for attending to the many facets and stages of the analysed cases. I close the article by offering insights into the retrograde impact of de-democratisation on gender and sexual equality. My focus on Macedonia, in accordance with Paternotte and Kuhar (2017), should not be understood as a suggestion that the addressed developments are unique, i.e., represent a 'Macedonian exception'. By providing extensive empirical material regarding one specific and thus far insufficiently explored context, I aim instead to inspire directions for future comparative analyses, which will better situate the Macedonian case within the European landscape of disturbing (un)democratic mobilisation against gender and sexual equality (Kováts, 2017; Kováts \& Põim, 2015; Kuhar \& Paternotte, 2017; Verloo, 2018).

\section{Legal Background}

Until 1991, the Republic of Macedonia was one of the constitutive units of the Socialist Federal Republic of Yugoslavia. No separate law on prevention and protection against discrimination existed. Macedonia's Crim- inal Code of 1977 addressed discrimination by criminalising the breach of citizens' equal rights on the grounds of 'nationality, ethnic background, race, faith, [assigned] sex, language, education, or societal status' (Služben vesnik na Socijalistička Republika Makedonija, 25/1977, Article 50, p. 496). The same Criminal Code criminalised male homosexuality-there were no provisions on female homosexuality-as 'unnatural debauchery' for which one could 'be incarcerated for up to one year' (Služben vesnik na Socijalistička Republika Makedonija 25/1977, Article 101.2, p. 501). Given this stipulation, it is no surprise that sexual orientation was not specified as a ground upon which one's equality could be violated.

Male homosexuality was finally decriminalised in the Criminal Code of 1996. That was one of the obligations which Macedonia had agreed to meet upon becoming a member of the Council of Europe in November 1995. Even then, though, the altered article on the breach of the equal rights failed to explicitly mention sexual orientation. The list of grounds upon which one could unfairly receive unequal treatment stated '[assigned] sex, race, skin colour, ethnic and social background, political and religious conviction, property ownership, societal status, language, or another personal characteristic or circumstance' (Služben vesnik na Republika Makedonija, 37/1996, Article 137, p. 1539). The decriminalisation of male homosexuality did not bring a constitutional change either. Just like the previous versions of the constitution, those which were proclaimed after 1996 did not specify that one's equality was to be respected and protected also regardless of one's sexual orientation.

Macedonia's first law on marriage was passed in 1973. Until then, the legislation on family matters had been decided upon at the federal level. That law, just like the preceding and succeeding ones, including those enacted after 1991, defined marriage as an opposite-sex union. Hence, it has never been possible to form a legally recognised same-sex matrimony in Macedonia. Under certain conditions, cohabitation could qualify as marriage, but that, too, concerned the opposite-sex unions only. The constitution did not contain any definitions of marriage and cohabitation (Služben vesnik na Socijalistička Republika Makedonija, 35/1973; Služben vesnik na Republika Makedonija, 157/2008).

\section{Legislative Procedures}

\subsection{Antidiscrimination Law}

Already the first NGOs which in the early 2000s started to advocate the rights of LGBT people in Macedonia demanded the creation of an antidiscrimination law wherein sexual orientation would be one of the prohibited discrimination grounds. They prompted the au-

\footnotetext{
${ }^{1}$ I only analyse texts in Macedonian, which is the country's official language and the native language of its largest ethnic community: the ethnic Macedonians. Being, unfortunately, unable to understand the native language of the ethnic Albanians (the second-largest ethnic community in the country), no Albanian-language items are featured here.
} 
thorities and the general public that such a law was needed also in light of Macedonia's aspirations for becoming an EU member state. However, although Macedonia applied for EU membership in March 2004 and was given the status of an EU candidate country in December 2005, the then ruling Social Democratic Union of Macedonia (SDSM) ${ }^{2}$ failed to make any progress regarding the antidiscrimination law. It was only at the end of 2007 that the government, led by VMRO-DPMNE, announced the forthcoming start of the relevant law-making procedure. Under the auspices of the Ministry of Labour and Social Policy, the working group in charge of drafting this law was to incorporate NGO representatives, too (Helsinški komitet za čovekovi prava na Republika Makedonija \& Makedonska asocijacija za slobodna seksualna orientacija, 2005; Makedonska asocijacija za slobodna seksualna orientacija, 2008; Najčevska et al., 2002).

This analysis explores the last phase of the procedure, when 'sexual orientation' all of a sudden disappeared from the long list of 18 explicitly formulated discrimination grounds (many more than in the earlier related legislation), plus the general category 'any other discrimination ground'. This happened in late January 2010, when the government, represented by the Ministry of Labour and Social Policy, submitted a new draft to parliament. Up to then, all versions of the draft law, including the last one from November 2009 which was expected to go to parliament, contained the term 'sexual orientation' and there were no indications of its removal (Koalicija za zaštita i promocija na seksualnite i zdravstvenite prava na marginaliziranite zaednici, 2009; Vlada na Republika Makedonija, 2010). ${ }^{3}$ It appears that the government conceded to the inclusion of 'sexual orientation' in the antidiscrimination law because that was one of EU's conditions for granting visa liberalisation to Macedonia. Once the EU positively decided upon the liberalisation in late November 2009, without having awaited the promulgation of the antidiscrimination law, the government deleted the parts of the draft law it disagreed with (Kacarska, 2015).

The Minister of Labour and Social Policy provided contradictory explanations for the removal. He stated both that the discrimination based on sexual orientation fell under 'any other discrimination ground' and that the inclusion of sexual orientation was 'not in accordance with the Constitution and the laws of the Republic of Macedonia' (BBC Macedonian, 2010). At that moment, though, there were six laws (the seventh was passed only two weeks later) which explicitly listed 'sexual orientation' as one of the grounds which could not justify unequal treatment. For example, the Law on Protection of Patients' Rights (Služben vesnik na Republika Makedonija, 82/2008), unambiguously defined that the reali- sation of those rights was not to be impeded due to one's sexual orientation. Even by using the least malign defence of the erasure, i.e., by stating that 'sexual orientation' was subsumed in 'any other discrimination ground', the proponents of the law ignored the importance of an explicit mention of this ground in order to discourage more successfully the unequal treatment of a highly marginalised population.

In the ensuing parliamentary debates, the oppositional parties and the involved NGOs demanded a withdrawal of this draft, which whitewashed the widespread discrimination of LGBT people, was not in accordance with the EU acquis, and ignored the concerns and recommendations which the Venice Commission ${ }^{4}$ and the OSCE Office for Democratic Institutions and Human Rights had expressed to earlier drafts. VMRO-DPMNE's parliamentarians unhesitatingly rejected not only the criticism coming from domestic actors, but also that of members of the European Parliament, foreign ambassadors, international human rights organisations, and the EU Delegation to Macedonia. Foreign politicians and activists were accused of supporting the agenda of the oppositional SDSM and, thereby, promoting values which did not correspond to the tradition of the Macedonian society. The inclusion of 'sexual orientation' was seen as potentially causing societal unrests and largely facilitating the demands for the detrimental legalisation of same-sex marriages and adoptions by same-sex couples. One deputy argued that in democratic societies 'the non-governmental organisations are not legitimate subjects and do not have the sovereignty' to monitor and control the work of the authorities (Komisija za evropski prašanja, 2010, p. 4). This statement clearly showed VMRO-DPMNE's distorted conceptualisation of democracy which precluded the more than necessary existence of citizens' critical engagement with the actions and policies of the authorities (Fouéré, 2016; Koalicija za zaštita i promocija na seksualnite i zdravstvenite prava na marginaliziranite zaednici, 2011; Najčevska, 2010).

After it had become obvious that the government did not intend to withdraw the draft law, a group of oppositional parliamentarians submitted to parliament in early March 2010 another draft antidiscrimination law. This draft was prepared by a number of NGOs and contained the term 'sexual orientation'. During that month, thus, parliament discussed two drafts. Given the safe majority which the ruling coalition had, the oppositional draft was rejected right after first reading, whereas the governmental draft was found acceptable to be sent to second reading. The debates which took place that month were full of misleading and contradictory information, as well as phobic and discriminatory utterances by VMRO-DPMNE's parliamentarians and government offi-

\footnotetext{
2 VMRO-DPMNE's main political rival.

${ }^{3}$ This was not the only staggering and problematic alteration, but the other issues do not fall under the scope of this analysis.

${ }^{4}$ Officially called 'European Commission for Democracy through Law', this advisory body of the Council of Europe serves to provide legal advice 'to its member states and, in particular, to help states wishing to bring their legal and institutional structures into line with European standards and international experience in the fields of democracy, human rights and the rule of law' (Retrieved from www.venice.coe.int/WebForms/pages/ $? p=01 \_$Presentation).
} 
cials. They insisted that the inclusion of 'sexual orientation' was part of SDSM's agenda to change the Family Law, i.e., legalise the unnatural same-sex marriages and adoptions by same-sex couples. In their view, that change would take away all legal obstacles to the later legalisation of incest, paedophilia, polyandry, polygamy, and zoophilia. Homosexuality was portrayed as an illness and a deviant Western phenomenon, which led to decadence and national self-destruction, and was antithetical to the local traditions and values as endorsed by the Macedonian Orthodox Church and the Islamic Religious Community ${ }^{5}$-an argument which directly undermined the constitutionally guaranteed secularism. The rights of homosexual people were called 'quasi human rights' and the struggle for their achievement was presented as irrelevant because, as it was claimed, those people already enjoyed all rights and were not discriminated by anybody in the tolerant Macedonian society. At the same time, VMRO-DPMNE and the government in general were portrayed as committed to human rights and EU membership, and as respecting and following the EU standards and values (Anketna komisija, 2010; Dimitrov, 2015; Koalicija za zaštita i promocija na seksualnite i zdravstvenite prava na marginaliziranite zaednici, 2011; Sobranie na R. Makedonija, 2010a).

So, instead of providing space for a substantial debate on equality, the ruling VMRO-DPMNE 'abused the law-making procedure to promote discriminatory behaviour [and] unbridled hate speech by many parliamentarians' (Najčevska, as cited in Makedonski centar za meǵunarodna sorabotka, 2010). Once parliament received a new version of the governmental draft law in the second half of March 2010, there was a significant reduction of the overt utterances of discrimination and hate speech. Nonetheless, the amendment for adding 'sexual orientation', proposed by a deputy from one of VMRO-DPMNE's smaller coalition partners, was rejected and the new draft was supplemented with a definition of marriage as 'a life union exclusively of one man and one woman' (Komisija za trud i socijalna politika \& Zakonodavno-pravna komisija, 2010, p. 4). In view of the already existing definition of marriage in the Family Law, this supplement was legally superfluous, but it served to further install VMRO-DPMNE's heteronormative agenda. The addition of the word 'exclusively', which was absent from the corresponding definition in the Family Law, strengthened this endeavour. It seems, therefore, that VMRO-DPMNE, having reached its goal, temporarily abstained from spreading moral panic about the imposition of homosexuality, only to return to it in a big way three years later, during its attempts to introduce constitutional changes.

On 8 April 2010, the new draft of the antidiscrimination law-officially called Law on Prevention and Protection against Discrimination - was swiftly passed by parlia- ment. By way of protest, the oppositional parliamentarians were either absent or abstained from the final debate and the voting. ${ }^{6} \mathrm{~A}$ week earlier, the European Commissioner for Enlargement and European Neighbourhood Policy warned once more the Macedonian Prime Minister (and VMRO-DPMNE's leader) about the problematic character of the proposed draft. He stressed the importance of respecting the EU acquis and mentioning 'sexual orientation' as a discrimination ground, and added that its exclusion 'could paradoxically, be seen as a form of discrimination' (Füle, as cited in Fouéré, 2016, p. 227). Referring to the oft-mentioned alleged causality between the inclusion of 'sexual orientation' and the introduction of same-sex marriages, the Commissioner pointed that while all EU member states considered sexual orientation a potential discrimination ground, their family laws were not affected by that and differed greatly. Unfortunately, even this letter and the related advocacy attempts by the Head of the EU delegation to Macedonia did not thwart the adoption of the law (Fouéré, 2016; Služben vesnik na Republika Makedonija, 50/2010; Sobranie na R. Makedonija, 2010b).

In its 2010 progress report for Macedonia, the European Commission (2010, pp. 19-20), next to criticising the country for passing such an antidiscrimination law, commented on the overall procedure, too: 'The quality of the dialogue on the law was low. The debates in parliament were divisive and remarks from civil society and the international community were not considered'. That comment would prove to be valid also for the procedures concerning the abortion law and the constitutional changes.

\subsection{A Constitutional Definition of Marriage}

On 29 December 2010, during their New Year's meeting with the President of Macedonia, the representatives of the five main religious communities in Macedonia presented their call for a constitutional definition of marriage as an opposite-sex union and invited all citizens and deputies to support their endeavour. The ruling VMRODPMNE said not to be familiar with this request, but considered it a legitimate effort of those who 'cared for the health of the citizens and the nation, as well as for the preservation of moral values' (Makfaks, 2010). Although the news reports of the meeting did not note an explicit utterance of support by this party, it is difficult to imagine its absence. There was a large overlap between the relevant discourse of the Macedonian Orthodox Church and that which VMRO-DPMNE used in its defence of the removal of 'sexual orientation' from the antidiscrimination law.

Its unambiguous rejection of same-sex marriages notwithstanding, VMRO-DPMNE did not speak of introducing a constitutional definition of marriage. That was

\footnotetext{
${ }^{5}$ The two largest religious authorities in Macedonia.

${ }^{6}$ Absenteeism is a common, albeit typically unsuccessful, protest strategy of the parliamentarian opposition in Macedonia, regardless of which political parties constitute that opposition.
} 
not the case even in October 2012, when the issue of same-sex marriages and adoptions resurfaced again. On the occasion of the International Day of the Girl Child, the Minister of Labour and Social Policy asserted that there would be no gay marriages in Macedonia nor adoptions by same-sex couples as long as VMRO-DPMNE was in power. According to him, the only way for a child to develop normally was to be raised by its biological parents. Just a day later, in an interview on one of the main pro-government TV stations, he underlined that these standpoints were in accordance with his party's Christian and traditional values. Responding to the criticism of several NGOs which qualified his statements as discriminating against LGBT people, adopted children, and single and adoptive parents, the Minister said that he did not understand this exaggerated reaction and threatened the NGOs with a libel lawsuit (which he eventually did not set in motion). Few days later, his fellow party member, the Minister of Internal Affairs, similarly spoke of opposite-sex marriages as being based on natural principles and considered the adoptions by same-sex couples as not leading to the nation's prosperity. Her comment, too, was given at an event which was unrelated to the issues at stake: The EU Anti-Trafficking Day (E-vesti, 2012; E. Š., 2012; Koalicija "Seksualni i zdravstveni prava na marginaliziranite zaednici", 2013). Shortly afterwards, in his festive speech given on a Macedonian national holiday, the Prime Minister called for respect for traditional family values and portrayed same-sex marriages and adoptions by same-sex couples as 'distorted values', just like the struggle for women's rights and women's political and economic participation (Vlada na Republika Makedonija, 2012).

The silence on the potential constitutional definition of marriage was soon to end. In early August 2013, a group of deputies from the ruling coalition submitted to parliament an initiative for constitutional changes. In hindsight, one can say that the preceding homophobic statements-including the Minister of Health's resolute rejection in June 2013 of the chance of introducing same-sex marriages and gender reassignment surgeries (A1on, 2013)-were a harbinger of the requested constitutional changes: the insertion of the exclusive definition of marriage and cohabitation as a union of one man and one woman, and the insertion of the restrictive stipulation that only a married opposite-sex couple or a single parent could adopt children. The initiative did not mention the terms 'homosexuality' and 'same-sex', but these terms were to be inferred from the formulation that the institution of marriage was 'faced with the modern-day challenges [and] efforts for its redefinition' (Grupa pratenici, 2013, p. 7). While acknowledging the existence of a definition of marriage in both the Family Law and the Law on Prevention and Protection against Discrimination, the initiators suggested that those stipulations were insufficient. The deputies argued that Mace- donia needed to invoke constitutional mechanisms to additionally protect the traditional definition of marriage, the family values, children's wellbeing, and the society in general. Contrary to the constitutionally guaranteed secularism, one of the provided justifications was that all religious communities in Macedonia conceptualised marriage as a union of one man and one woman-an implicit reference to the call of the religious leaders from December 2010.

Prior to the parliamentary debate in September 2013, the government sent to parliament a letter in support of the changes. Besides repeating the arguments about the importance of increased protection, the government stated that such a constitutional definition was needed 'lest a legal lacuna remains which would allow space for various interpretations (Vlada na Republika Makedonija, 2013 , p. 2). This statement, however, misrepresented the reality: the Family Law left no space for interpretations. Already at the beginning of the debate, VMRODPMNE's deputies explicitly stated that without a constitutional definition of marriage, it would be much easier for SDSM, should it come to power, to legalise same-sex unions and adoptions by same-sex couples. Thus, it became clear that the real issue at stake was not the alleged legal lacuna, but the difference between the number of parliamentarians needed to change a law (42) and that needed to change the constitution (82).

As before, VMRO-DPMNE used deception to spread panic and advance its agenda. The proposal of the Macedonian Helsinki Committee to change the Family Law so that the provisions against domestic violence would also apply to same-sex couples was interpreted as a demand for legalisation of same-sex marriages. Furthermore, that action was portrayed as not being a genuine non-party initiative, but as orchestrated by SDSM. The Macedonian Helsinki Committee and other oppositional NGOs were additionally depicted as championing foreign interests and working in bad faith due to being funded by the billionaire George Soros through his Open Society Foundations-one of VMRO-DPMNE's oft-used ways for delegitimising the NGOs which publicly disagreed with its politics. ${ }^{7}$ In short, the parliamentarians and the public were time and again warned about the apparent threat which all dissenting voices posed to the Macedonian society and its traditions.

Despite all this insistence and many deputies' (some of whom were from the non-ruling parties) deeply worrisome homophobic utterances and/or lack of even basic knowledge of gender and sexuality related matters and terminology, the initiative did not obtain the required number of affirmative votes. Unlike before, VMRO-DPMNE's main coalition partner since 2008, the ethnic Albanian party DUI (Democratic Union for Integration), withheld its support. As DUI's deputies repeatedly stated during the debate, they, too, considered the traditional and religiously sanctioned opposite-sex marriage

\footnotetext{
${ }^{7}$ Cf. the similar strategies of the authorities in Hungary recently (Trencsényi, Rieber, lordachi, \& Hîncu, 2017) and of those in Croatia and Serbia in the 1990s (Stubbs, 2013).
} 
the only possible form of marriage, but they were not interested in any minor and partial constitutional interventions. Portraying themselves as vigilant advocates of their constituency, the only changes these deputies were willing to support were the profound ones for the purpose of granting more rights and decision-making power to the ethnic Albanians (Helsinški komitet za čovekovi prava na Republika Makedonija, 2012; Sobranie na R. Makedonija, 2013a, 2013b; Staletović, 2016).

In late June 2014, less than a year after the first attempt, VMRO-DPMNE pushed again for a constitutional definition of marriage and cohabitation. At that moment, most of the opposition boycotted parliament in protest against the irregularities during the parliamentary and presidential elections in April 2014. This new proposal was put forward by the government, as part of a set of quite diverse constitutional changes ${ }^{8}$, unlike the earlier one, which only addressed marriage and cohabitation. The Prime Minister presented the changes as bringing new quality and higher standards to the country. Comparable to the discourse of modernisation which the government had employed for defending the restrictive abortion law, the notion of improvement was used to mask another intended introduction of a discriminatory or otherwise harmful policy (Miškovska Kajevska, 2018; Vlada na Republika Makedonija, 2014a, 2014b). ${ }^{9}$ Although the proposed interventions did not address the issues which DUI had underlined during the earlier initiative for constitutional changes, this time its parliamentarians and government officials supported the proposal.

Parliament authorised the start of the procedure for changing the constitution in mid-July 2014. Subsequently, the government had ten days to formulate related draft amendments and submit them to parliament. When parliament received those amendments, it turned out that the government wanted to constitutionally define cohabitation, too. That intervention had not been previously discussed in parliament, i.e., it was not part of the document which had been approved the month before. So, all of a sudden, the draft amendment on marriage contained two parts: one defining marriage as a 'union exclusively between only one woman and only one man' and another doing the same regarding 'registered cohabitation, or any other registered form of life partnership' (Vlada na Republika Makedonija, 2014c, p. 2). Prior to the related parliamentary session in late August 2014, the Minister of Justice had requested the opinion of the Venice Commission on the whole set of draft amendments, but even before that opinion was delivered, they were approved by parliament. In a selfcontradictory manner the proponents resorted again to religion and tradition to underline the supposed natural and unchanging character of the opposite-sex marriage, and to justify the need to constitutionally protect it. Much more striking was the fact that, with the exception of three deputies (two oppositional ones and one from a smaller member of the ruling coalition), the rest did not object to the unannounced and undiscussed extension of the amendment on marriage. By breaching the official legislative procedure, the government and parliament alike thus undermined democracy and the rule of law, all the while claiming that the requested constitutional changes served to improve the state administration (Sobranie na R. Makedonija, 2014).

After being approved, the draft amendments were subjected to a 30-day open public debate. Many (LGBT) human rights activists stressed-just like the Venice Commission would state later-that it was not necessary to constitutionally define marriage because the Family Law already contained the same stipulation, whereas the added second definition collided with the rulings of the European Human Rights Court. To obtain support against this constitutional change, the activists spoke in local and foreign media, and alerted their international networks and the diplomatic corps in Macedonia. After the Venice Commission had delivered its opinion in October 2014, the Minister of Justice held a press-conference in which he implied that the definition of cohabitation would be removed. Without referring to the objections made during the public debate, he expressed the government's willingness to respect the opinion of the Venice Commission. The second version of the draft amendments which parliament received in late December 2014 did not contain the definition of cohabitation (Duvnjak, 2014; Trajanoski, 2015; Venice Commission, 2014; Vlada na Republika Makedonija, 2014d).

The next relevant parliamentary session, scheduled for the second half of January 2015, was expected to end with the pronouncement of the constitutional changes. The parliamentarians from the ruling coalition approved the contents of each of the amendments, but when the final voting on the whole set was supposed to begin, there were fewer deputies present than required. As a result of the internal power struggles in DUI regarding, inter alia, the changes which the ethnic Albanians were to support, four of its parliamentarians decided to disrespect the agreement between their party leader and the leader of VMRO-DPMNE and leave the session. Due to this absence of a quorum the session was interrupted and has not been resumed since. In consequence, the constitution has remained free from a heteronormative definition of marriage (Sobranie na R. Makedonija, 2015a, 2015b).

\section{Discussion: De-Democratisation as a Catalyst for Gender and Sexual Inequality}

One of the reasons why the procedure for changing Macedonia's constitution has not been resumed was the disclosure in February 2015 of the mass illegal wiretap-

\footnotetext{
${ }^{8}$ I do not address here the other proposed changes because they were not related to gender and sexual equality.

${ }^{9}$ Another example is the purchase of dated and lower quality insulin for the diabetes patients which was announced as procurement of the 'most modern therapy' (Stojadinovik, 2016).
} 
ping operation run by the state intelligence service. The leader of SDSM revealed that around $1 \%$ of the country's population, i.e., around 20,000 people, had been wiretapped, including (prominent) members of the ruling coalition. After receiving the recordings of those intercepted phone, e-mail, and text communications, he publicly aired some of them. The recordings exposed the large extent of the ruling parties' abuse of power, that of VMRO-DPMNE in particular: mass forgery and sabotage of the electoral process and the electoral register, threats to people lest they vote for another party, physical violence against opponents, blackmail, extortion, corruption, as well as extensive control of the media, judiciary, police, and other state institutions (European Commission, 2015; Senior Experts' Group, 2015). In the 2016 progress report for Macedonia, the European Commission (2016, p. 8) expressed its 'concerns about state capture of institutions and key sectors of society', i.e., the fact that 'independent regulatory, supervisory and advisory bodies were not able to carry out their functions proactively, effectively and free from political pressure, leading to limited oversight of the executive'. Therefore, following Tilly's (2007, p. 20) categorisation of regimes' public politics, one can say that in the analysed decade Macedonia was a 'high-capacity undemocratic' state-an extent of state capture, infringement of procedures, and suppression of free choice which was unprecedented since the fall of the socialist polity.

This is not to say that the first 15 years of Macedonia's existence as an independent political entity were marked by a thriving development of democracy. Neither were the pre-2006 governments led by VMRO-DPMNE or SDSM exemplary proponents of the rule of law, a good functioning trias politica, and extensive citizen participation in the decision and law-making processes (see, e.g., the annual reports of the Macedonian Helsinki Committee $\left.{ }^{10}\right)$. Furthermore, between 1991 and 2006, the achievement of gender and sexual equality was far from a priority for the ruling parties. ${ }^{11}$ They made no significant improvements in the form of, e.g., creation of an antidiscrimination law, institution of a constitutionally guaranteed equality of sexual minorities, opening up of marriage and cohabitation for same-sex couples, increased access to modern contraception, or incorporation of a comprehensive sexual education in the curricula. Depending on the issue, that non-action, i.e., the preservation of the status quo could either facilitate the realisation of gender and sexual equality (e.g., termination of pregnancy) or obstruct it (e.g., discrimination on the grounds of sexual orientation).

After the parliamentary elections in 2006, though, the situation increasingly started deteriorating. VMRODPMNE's refusal to explicitly oppose the discrimination on the grounds of sexual orientation, and its objections to same-sex marriages and the struggle for women's rights, formed a highly problematic political programme, which put roadblocks on the route to gender and sexual equality. This programme became even much more worrisome because it remained in place for a decade and was combined with an advancing de-democratisation. In other words, the gender and sexual Others were already put in a disadvantaged position, which significantly hampered their equal participation and treatment in the society. The state capture and the systematic suppression of dissent were already generally detrimental for democracy and the majority of the population, but they additionally prevented the already marginalised groups from freely exercising their rights and liberties.

The authorities did not stop at ignoring or discarding the criticism which was put forward by non-ruling parties and the few professionals, NGO activists and ordinary citizens who dared to utter their dissent. Even the concerns and recommendations of EU institutions and other supranational bodies were hardly taken into account. Misleading information was regularly communicated, such as the framing of the promoted regressive changes as modernisation. (A contradiction existed, though, in the utterances regarding the constitutional definition of marriage: marriage was to be protected from the 'modern-day challenges' by modernisation.) Moreover, utterances of discrimination, homophobia, and hate speech, as well as breaching of the official procedures became an everyday reality. Instead of leading to sanctions for the perpetrators, those occurrences became normalised.

In addition, the constitutionally guaranteed secularism was violated through the involvement of religious officials and politicians' recourse to religion for the purpose of justifying the proposed interventions. This means that, unlike in Croatia and Slovenia-two other post-Yugoslav states-where the initially clerical discourse of the opponents of gender and sexual equality has been secularised (Hodžić \& Štulhofer, 2017; Kuhar, 2015), in Macedonia the initially secular discourse was clericalised. Based on the analysis of these authors, another difference between the contexts in question becomes visible. In Croatia and Slovenia, the main religious authority (the Catholic (hurch) and its NGO subsidiaries have been in the public forefront of the campaigning against gender and sexual equality, whereas the secular authoritiesthe government and parliamentary officials-have taken a secondary part. These roles were reversed in Macedonia: The secular authorities there were the key public opponents of this equality, while the main religious authority (the Macedonian Orthodox Church) foremostly conducted its advocacy efforts in the background. No extensive presence of religiously affiliated NGOs was visible. At the same time, comparably to Croatia and Slovenia (Hodžić \& Štulhofer, 2017; Kuhar, 2015), deceptive information was used to impose heteronormativity and

\footnotetext{
10 The reports are available on the Committee's webpage: http://www.mhc.org.mk/pages/reports

11 The decriminalisation of male homosexuality in 1996 stemmed from the requirements of the Council of Europe, not the genuine engagement of the then Macedonian authorities.
} 
multi-child nuclear families, and portray homosexuality, same-sex marriages, and abortion as a highly potent societal threat.

The addressed developments in Macedonia seem to fit within the broader mobilisation against gender and sexual equality across Europe-e.g., Austria, Croatia, France, Italy, Poland, and Russia-which is carried out by conservative political and religious forces (Kováts, 2017; Kováts \& Põim, 2015; Kuhar \& Paternotte, 2017; Verloo, 2018). However, unlike elsewhere, where the terms 'gender ideology' and/or 'gender theory' are more often than not employed to name the danger one (preventively) mobilises against, such terms were absent from the relevant discussions in Macedonia in the analysed decade. When the admission of new students of Gender Studies at the main state university was discontinued in 2013 and the start of the brand new Family Studies was announced, the provided justifications did not feature the above terms, but referred to the surplus of Gender Studies graduates on the labour market and the shortage of expertise related to the topics which would be covered by the Family Studies. The introductory text of their programme even stated that they were based, too, in the knowledge obtained by the Gender Studies (Fakulteti, 2013; Filozofski fakultet, 2013). This quite curious situation, which took place in the same year in which the restrictive abortion law was promulgated, deserves to be further explored in a separate analysis.

After the parliamentary elections in December 2016, VMRO-DPMNE's animosity towards democracy became once more shockingly obvious. Although this party won the elections (by a narrow margin from SDSM), it did not succeed to form a government. VMRO-DPMNE's diverse obstructions of the subsequent related procedures included the refusal of the head of the state, who had won the presidential elections as that party's candidate, to grant the mandate for forming a government to the leader of SDSM. On 27 April 2017, after the SDSM-led parliamentary majority elected the new speaker, the supporters of VMRO-DPMNE, assisted by some of its deputies, stormed the parliament and (severely) injured several parliamentarians from SDSM and the ethnic Albanian political parties, as well as journalists. The President spoke of declaring a state of emergency-a situation, which would have enabled him and the other officials of the captured state to even more severely bypass the democratic procedures (Walby, 2015). Following intense international diplomatic pressure, the President and VMRO-DPMNE had to back down. In May 2017, SDSM managed to form a government. This gives space for optimism, although the system of unlawful control and coercion cannot be dismantled overnight. Furthermore, SDSM's democratic record is far from impeccable and its support to women's and LGBT rights inconsistent, whereas DUI, which remained in power as the main ethnic Albanian coalition partner, has never championed those rights. It remains, therefore, to be seen how the situation in Macedonia will develop further, also in connection to gender and sexual equality (Denkovska, 2017; European Parliament, 2017; Helsinški komitet za čovekovi prava na Republika Makedonija, 2017; The Economist, 2017).

\section{Conclusion}

To better understand the legislative interventions in the area of gender and sexual equality in Macedonia, one should see them in connection to the wider practices of de-democratisation progressively undertaken between 2006 and 2017. Put differently, the discourses and activities against gender and sexual Others were not only a result of the decade-long rule of conservative parties, VMRO-DPMNE in particular, but also of their installation of a comprehensive suppression of dissent and de facto abolishment of the separation of powers. Given that democracy always involves contestation between political actors, whether from civil society or government (Walby, 2015), such a severe restriction of the possibilities for expressing contestation meant a severe dedemocratisation of the Macedonian state and society in general.

Nonetheless, opposition to gender and sexual equality is not uniform and necessarily related to undemocratic processes, but has many varieties (Verloo, 2018). For example, it can be manifested in the form of street protests in France, articles and books in Germany, online violence in Sweden, and avoidance to implement policies by bureaucratic actors in the European Commission (Kuhar \& Paternotte, 2017; Verloo, 2018). Far from negligible opposition can also flourish, thus, in contexts where democracy is (much) less endangered compared to Macedonia. However, when the institutional mechanisms for safeguarding against violence and discrimination, promoting and enforcing equality, and allowing space for overt expressions of dissent are seriously undermined, obstructed or even turned into auxiliaries of the parties in power, the struggle against the unfavourable trends becomes even more difficult. That is why the efforts to achieve gender and sexual equality cannot be detached from the efforts to maintain and improve democracy, transparency, and human rights and liberties in general.

The diverse forms of opposition to gender and sexual equality and their intertwinement with the larger political context require that scholars apply a broad and delicate lens for detecting that opposition and the factors which contribute to its strengthening or weakening. As the above example of the eventually unsuccessful attempt at constitutional changes shows, the promulgation of a new legislation or policy depends not only on the opinions and values which are promoted by the ruling parties, but also on the outcome of the horse trading between them, and the (unforeseen) actions of third parties. 


\section{Acknowledgments}

I am grateful to Mieke Verloo, David Paternotte, and Dejan Guzina, the two peer reviewers, and the other fellow scholars who commented upon earlier drafts. I also acknowledge the financial support of the European Consortium for Political Research and the Political Science Department of the University of Amsterdam which enabled me to discuss this article at the ECPR Joint Sessions (Nottingham, April 2017) and the ASN World Convention (New York, May 2018), respectively.

\section{Conflict of Interests}

The author declares no conflict of interests.

\section{References}

A1on. (2013, June 7). Todorov prifati amandmanski intervencii na zakonot za prekinuvanje bremenost [Todorov accepted amendment interventions in the Law on pregnancy termination]. Alon. Retrieved from https://a1on.mk

Anketna komisija. (2010, March 16). Beleški od dvaesettata sednica na Anketnata komisija vo Sobranieto na Republika Makedonija, održana na 16 mart 2010 godina [Minutes of the 20th session of the committee of inquiry of the parliament of the Republic of Macedonia, held on 16 March 2010]. Sobranie na Republika Makedonija. Retrieved from www.sobranie.mk

BBC Macedonian. (2010, February 1). Makedonija i seksualnata diskriminacija [Macedonia and the sexual discrimination]. BBC Macedonian. Retrieved from www.bbc.co.uk/macedonian/archive/index.shtml

Denkovska, A. (2017, April 28). Sobranie: Nasilstvo, diveenje, pretepani pratenici i zaspana policija [Parliament: Violence, raging, beaten parliamentarians and sleeping police]. Nova TV. Retrieved from http://novatv.mk

Dimitrov, S. (2015). The triumphant distribution of the heteronormative sensible: The case of sexual minorities in transitional Macedonia, 1991-2012. In C. Hassenstab \& S. P. Ramet (Eds.), Gender (in)equality and gender politics in Southeastern Europe: A question of justice (pp. 231-254). London: Palgrave Macmillan.

Duvnjak, G. (2014, October 16). Vladata ne ja ignorira Venecijanska [sic] komisija [The government does not ignore the Venice Commission]. Utrinski vesnik. Retrieved from www.utrinski.mk

E. Š. (2012, October 12). Gej brakovi vo Makedonija nema da ima [There will be no gay marriages in Macedonia]. Večer. Retrieved from http://vecer.mk

European Commission. (2010). The former Yugoslav Republic of Macedonia 2010 progress report. Brussels, Belgium: European Commission. Retrieved from https://ec.europa.eu

European Commission. (2015). The former Yugoslav Republic of Macedonia report 2015. Brussels, Bel- gium: European Commission. Retrieved from https:// ec.europa.eu

European Commission. (2016). The former Yugoslav Republic of Macedonia 2016 report. Brussels, Belgium: European Commission. Retrieved from https:// ec.europa.eu

European Parliament. (2017, May 2). EP mediators call on President Ivanov to end the current crisis in Skopje. News European Parliament. Retrieved from www. europarl.europa.eu/news/en/press-room

E-vesti. (2012, October 18). Jankuloska: Samo brakot pomeǵu maž i žena e priroden [Jankuloska: The marriage between a man and a woman is the only natural one]. E-vesti. Retrieved from http://evesti.mk

Fakulteti. (2013, July 9). Započnuvaat semejnite studii, rodovite vo miruvanje [The Family Studies begin, the Gender ones on hold]. Fakulteti. Retrieved from www.fakulteti.mk

Filozofski fakultet. (2013). Proekt za voveduvanje na četirigodišna (240 krediti) studiska programa po semejni studii od I (prv) ciklus na studii na Filozofski fakultet [Project for the establishment of a four-year (240 credits) undergraduate study programme in Family Studies at the Faculty of Philosophy].

Fouéré, E. (2016). The curious case of Macedonia: A personal insight of a former Head of the EU Delegation in Macedonia. In K. Slootmaeckers, H. Touquet, \& P. Vermeersch (Eds.), The EU enlargement and gay politics: The impact of eastern enlargement on rights, activism and prejudice (pp. 221-232). London: Palgrave Macmillan.

Grupa pratenici. (2013). Predlog za pristapuvanje kon izmena na Ustavot na Republika Makedonija [Proposal to commence the change of the Constitution of the Republic of Macedonia]. Sobranie na Republika Makedonija. Retrieved from www.sobranie.mk

Helsinški komitet za čovekovi prava na Republika Makedonija. (2017). Poseben izveštaj za identifikuvani i možni krivični dela storeni za vreme na nasilstvoto vo Sobranieto na 27 april 2017 godina [Special report on the identified and potential criminal acts committed during the violence in the parliament on 27 April 2017]. Helsinški komitet za čovekovi prava na Republika Makedonija. Retrieved from www.mhc.org.mk

Helsinški komitet za čovekovi prava na Republika Makedonija (2012). Inicijativa za poveduvanje postapka za ocenuvanje na ustavnosta na odredba od zakon [Initiative to commence the procedure for reviewing the constitutionality of a law stipulation]. Helsinški komitet za čovekovi prava na Republika Makedonija. Retrieved from www.mhc.org.mk

Helsinški komitet za čovekovi prava na Republika Makedonija \& Makedonska asocijacija za slobodna seksualna orientacija. (2005). Identifikuvanje na LGBT populacijata vo Republika Makedonija-2004/2005 (rezultati od sprovedena anketa) [Identification of the LGBT population in the Republic of Macedonia-2004/2005 (survey results)]. Skopje: Helsinški 
komitet za čovekovi prava na Republika Makedonija \& Makedonska asocijacija za slobodna seksualna orientacija.

Hodžić, A., \& Štulhofer, A. (2017). Embryo, teddy bearcentaur and the constitution: Mobilizations against "gender ideology" and sexual permissiveness in Croatia. In R. Kuhar \& D. Paternotte (Eds.), Anti-gender campaigns in Europe: Mobilizing against equality (pp. 59-77). London and New York: Rowmann \& Littlefield International.

Kacarska, S. (2015). Losing the rights along the way: The EU-Western Balkans visa liberalisation. European Politics and Society, 16(3), 363-378.

Koalicija za zaštita i promocija na seksualnite i zdravstvenite prava na marginaliziranite zaednici. (2009). Godišen izveštaj za seksualni i zdravstveni prava na marginaliziranite zaednici [Annual report on the sexual and health rights of the marginalised communities]. Skopje: Koalicija za zaštita i promocija na seksualnite i zdravstvenite prava na marginaliziranite zaednici.

Koalicija za zaštita i promocija na seksualnite i zdravstvenite prava na marginaliziranite zaednici. (2011). Izveštaj za seksualnite i zdravstvenite prava na marginaliziranite zaednici vo Republika Makedonija [Report on the sexual and health rights of the marginalised communities in the Republic of Macedonia]. Skopje: Koalicija za zaštita i promocija na seksualnite i zdravstvenite prava na marginaliziranite zaednici.

Koalicija "Seksualni i zdravstveni prava na marginaliziranite zaednici". (2013). Godišen izveštaj: Zdravstveni i seksualni prava na pripadnici na marginalizirani grupi (korisnici na droga, lica što živeat so HIV, seksualni rabotnici i LGBTIQ) [Annual report: Health and sexual rights of the members of the marginalised communities (drug users, people who live with HIV, sex workers and LGBTIQ)]. Skopje: Koalicija "Seksualni i zdravstveni prava na marginaliziranite zaednici".

Komisija za evropski prašanja. (2010). Izveštaj [Report]. Sobranie na Republika Makedonija. Retrieved from www.sobranie.mk

Komisija za trud i socijalna politika and Zakonodavnopravna komisija (2010). Dopolnet predlog na zakon za sprečuvanje i zaštita od diskriminacija [Supplemented draft law on prevention and protection against discrimination]. Sobranie na Republika Makedonija. Retrieved from www.sobranie.mk

Kováts, E. (2017). The emergence of powerful antigender movements in Europe and the crisis of liberal democracy. In M. Köttig, R. Bitzan, \& A. Petö (Eds.), Gender and far right politics in Europe (pp. 175-189). London: Palgrave Macmillan.

Kováts, E., \& Põim, M. (Eds.). (2015). Gender as symbolic glue. The position and role of conservative and far right parties in the anti-gender mobilizations in Europe. Budapest: Foundation for European Progressive Studies \& Friedrich-Ebert-Stiftung.

Kuhar, R. (2015). Playing with science: Sexual citizenship and the Roman Catholic Church counter-narratives in Slovenia and Croatia. Women's Studies International Forum, 49, 84-92.

Kuhar, R., \& Paternotte, D. (Eds.). (2017). Anti-gender campaigns in Europe: Mobilizing against equality. London and New York: Rowmann \& Littlefield International.

Makedonska asocijacija za slobodna seksualna orientacija. (2008). Izveštaj 2007 [Report 2007]. Skopje: Makedonska asocijacija za slobodna seksualna orientacija.

Makedonski centar za meǵunarodna sorabotka. (2010). SITEL: Stav na MCMS za predlog-ZSZD [SITEL: MCMS' position on the draft law on prevention and protection against discrimination]. Retrieved from https://youtu.be/YEEX6HYWM4g

Makfaks. (2010, December 29). Verskite zaednici baraat ustavni izmeni [The religious communities request constitutional changes]. Makfaks. Retrieved from www.makfax.com.mk

Miškovska Kajevska, A. (2018). Suspending democracy, harming gender equality: The 2013 Law on pregnancy termination in Macedonia. In M. Verloo (Ed.), Varieties of opposition to gender equality in Europe (pp. 195-212). New York and London: Routledge.

Miškovska Kajevska, A. (2016). Growing oppression, growing resistance: LGBT activism and Europeanisation in Macedonia. In B. Bilić (Ed.), LGBT activism and Europeanisation in the post-Yugoslav space: On the rainbow way to Europe (pp. 81-116). London: Palgrave Macmillan.

Najčevska, M., Mladenoviḱ, N., Trajanoski, Ž., Cvetanovska, M., Balazhi, S., Trpčevska, G., . . J Jankovski, D. (2002). Granici na slobodata i izborot: homoseksualnosta vo Republika Makedonija [Limits to freedom and choice: Homosexuality in the Republic of Macedonia]. Skopje: Helsinški komitet za čovekovi prava na Republika Makedonija \& Centar za čovekovi prava i razrešuvanje konflikti.

Najčevska, M. (2010). Kako vlasta go ubi zakonot za zaštita od diskriminacija [How the authorities killed the Law on protection against discrimination]. Kvadratura na krugot. Retrieved from http:// kvadraturanakrugot.crnaovca.mk

Paternotte, D., \& Kuhar, R. (2017). "Gender ideology" in movement: Introduction. In R. Kuhar \& D. Paternotte (Eds.), Anti-gender campaigns in Europe: Mobilizing against equality (pp. 1-22). London and New York: Rowmann \& Littlefield International.

Senior Experts' Group. (2015, June 8). The former Yugoslav Republic of Macedonia: Recommendations of the Senior Experts' Group on systemic Rule of Law issues relating to the communications interception revealed in Spring 2015. Brussels, Belgium: European Commission. Retrieved from http://ec.europa.eu

Služben vesnik na Republika Makedonija. (37/1996). Krivičen zakonik [Criminal Code]. Retrieved from www.slvesnik.com.mk 
Služben vesnik na Republika Makedonija. (82/2008). Zakon za zaštita na pravata na pacientite [Law on protection of patients' rights]. Retrieved from www.slvesnik.com.mk

Služben vesnik na Republika Makedonija. (157/2008). Zakon za semejstvoto [Family law]. Retrieved from www.slvesnik.com.mk

Služben vesnik na Republika Makedonija. (50/2010). Zakon za sprečuvanje i zaštita od diskriminacija [Law on prevention and protection against discrimination]. Retrieved from www.slvesnik.com.mk

Služben vesnik na Socijalistička Republika Makedonija. (35/1973). Zakon za brakot [Marriage law]. Retrieved from www.slvesnik.com.mk

Služben vesnik na Socijalistička Republika Makedonija (25/1977). Krivičen zakon [Criminal code]. Retrieved from www.slvesnik.com.mk

Sobranie na R. Makedonija. (2010a). Stenogram od sednica br. 95, točka 23 [Proceedings of the 95th session, item 23]. Retrieved from www.sobranie.mk

Sobranie na R. Makedonija. (2010b). Stenogram od sednica br. 100, točka 21 [Proceedings of the 100th session, item 21]. Retrieved from www.sobranie.mk

Sobranie na R. Makedonija. (2013a). Stenogram od sednica br. 72, točka 1 [Proceedings of the 72 nd session, item 1]. Retrieved from www.sobranie.mk

Sobranie na R. Makedonija. (2013b). Stenogram od sednica br. 72, točka 1 (prvo prodolženie) [Proceedings of the 72nd session, item 1 (first continuation)]. Retrieved from www.sobranie.mk

Sobranie na R. Makedonija. (2014). Stenogram od sednica br. 12, točka 1 [Proceedings of the 12th session, item 1]. Retrieved from www.sobranie.mk

Sobranie na R. Makedonija. (2015a). Stenogram od sednica br. 30, točka 1 [Proceedings of the 30th session, item 1]. Retrieved from www.sobranie.mk

Sobranie na R. Makedonija. (2015b). Stenogram od sednica br. 30, točka 1 (vtoro prodolženie) [Proceedings of the 30th session, item 1 (second continuation)]. Retrieved from www.sobranie.mk

Staletović, B. (2016). Elections in Macedonia: Intensification of nationalist and authoritarian tendencies. Contemporary Southeastern Europe, 4(1), 1-11.

Stojadinovik, S. (2016, June 29). Tendersko poigruvanje so životite na graǵanite so dijabetes [Procurement gamble with the lives of the citizens with diabetes]. Plusinfo. Retrieved from www.plusinfo.mk

Stubbs, P. (2013). Flex actors and philanthropy in (post)conflict arenas: Soros' Open Society Foundations in the post-Yugoslav space. Croatian Political Science Review, 50, 114-138.

The Economist. (2017, April 28). Macedonian nationalists storm the parliament to hold on to power. The Economist. Retrieved from www.economist.com

Tilly, C. (2007). Democracy. New York, NY: Cambridge University Press.

Trajanoski, Ž. (2015). Godišen izveštaj 2014: Seksualni i zdravstveni prava na marginaliziranite zaednici [Annual report 2014: Sexual and health rights of the marginalised communities]. Skopje: Koalicija "Seksualni i zdravstveni prava na marginaliziranite zaednici".

Trencsényi, B., Rieber, A. J., Iordachi, C., \& Hîncu, A. (2017). Academic freedom in danger. Fact files on the 'CEU affair'. Südosteuropa, 65(2), 412-436.

Venice Commission. (2014). Opinion on the seven amendments to the constitution of "the former Yugoslav Republic of Macedonia". Council of Europe. Retrieved from www.venice.coe.int

Verloo, M. (Ed.). (2018). Varieties of opposition to gender equality in Europe. New York and London: Routledge.

Vlada na Republika Makedonija. (2010). Predlog-zakon za sprečuvanje i zaštita od diskriminacija [Draft law on prevention and protection against discrimination]. Retrieved from www.sobranie.mk

Vlada na Republika Makedonija. (2012). Gruevski: VMRO istoriski prepoznatliv kod na makedonskiot narod [Gruevski: VMRO a historically recognisable code of the Macedonian nation]. Retrieved from http:// vlada.mk

Vlada na Republika Makedonija. (2013). Mislenje po Predlogot za pristapuvanje kon izmena na Ustavot na Republika Makedonija, podnesen od grupa pratenici [Opinion on the proposal to commence the change of the Constitution of the Republic of Macedonia, submitted by a group of parliamentarians]. Retrieved from www.sobranie.mk

Vlada na Republika Makedonija. (2014a). Predlog za pristapuvanje kon izmena na Ustavot na Republika Makedonija [Proposal to commence the change of the Constitution of the Republic of Macedonia]. Retrieved from www.sobranie.mk

Vlada na Republika Makedonija. (2014b). Gruevski: Icijativata [sic] za izmena na Ustavot ke znači nov kvalitet i povisoki standardi [Gruevski: The initiative to change the Constitution will mean new quality and higher standards]. Retrieved from http://vlada.mk

Vlada na Republika Makedonija. (2014c). Tekst na nacrtot na amandmanite XXXIII, XXXIV, XXXV, XXXVI, XXXVII, XXXVIII i XXXIX na Ustavot na Republika Makedonija [Contents of the draft amendments XXXIII, XXXIV, $X X X V, X X X V I, X X X V I I, X X X V I I I$ and XXXIX of the Constitution of the Republic of Macedonia]. Retrieved from www.sobranie.mk

Vlada na Republika Makedonija. (2014d). Tekst na predlog-amandmanite XXXIII, XXXIV, XXXV, XXXVI, XXXVII, XXXVIII, XXXIX i XL na Ustavot na Republika Makedonija [Contents of the draft amendments $X X X I I I, X X X I V, X X X V, X X X V I, X X X V I I, X X X V I I I, X X X I X$ and $X L$ of the Constitution of the Republic of Macedonia]. Retrieved from www.sobranie.mk

Walby, S. (2011). The future of feminism. Cambridge and Malden: Polity Press.

Walby, S. (2015). Crisis. Cambridge and Malden: Polity Press. 


\section{About the Author}

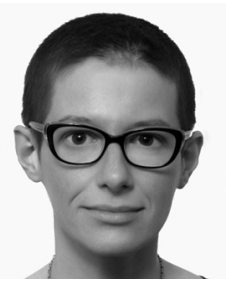

Ana Miškovska Kajevska is a researcher and activist, affiliated with the Political Science Department of the University of Amsterdam. Her PhD dissertation won the ECPR 2015 Gender and Politics PhD Prize and was published by Routledge in 2017. The book, Feminist Activism at War: Belgrade and Zagreb Feminists in the 1990s, was nominated for the 2018 Joseph Rothschild Prize in Nationalism and Ethnic Studies. 